\title{
CLUTCHES, NEST ATTENDANCE, AND HATCHING IN A ROCK-CAVE-DWELLING FROG, ELEUTHERODACTYLUS (SYRROPHUS) ZEUS, FROM CUBA
}

\author{
Roberto Alonso Boschi*, L. Yusnaviel García², Sergio del Castillo Domínguez³, \\ Eglis L. Torres MARTíneZ ${ }^{3}$
}

\begin{abstract}
The Cuban archipelago hosts at least thirteen endemic species of the genus Eleutherodactylus that live in association with rocks, caves, or limestone landscapes. However, the reproductive biology of Cuban rock-cave dwelling frogs has received little attention. In this contribution, we offer the first report of oviposition, clutch size, nest site locations, and hatching in Eleutherodactylus (Syrrophus) zeus. Clutches of this species in different development stages were sighted in rock depressions and crevices inside of the Gran Caverna de Santo Tomás, located in Sierra de Quemados, Viñales, Pinar del Río province. Clutch sizes ranged from 48 to 74 eggs, and hatching success was $98 \%$ for one of them. Moreover, we document the first report of nest attendance by a species of the subgenus Syrrophus, the strategy of which may be biparental, with either male or female parental care. Our findings are important not only in understanding general life-history strategies, but also in understanding particular strategies for an endemic species whose habitat specialization is associated with an at-risk system.
\end{abstract}

\section{INTRODUCTION}

The genus Eleutherodactylus, with more than 180 described species, is one of the largest genera of vertebrates. The species of this genus are the dominant terrestrial anuran component of most Caribbean-island forests, and most of these species lay terrestrial or arboreal eggs that undergo direct development into miniature froglets (Henderson and Powell, 2009). Eleutherodactylus species have experienced extensive island radiations with subsequent morphological, behavioral, and ecological diversification, colonizing a wide variety of microhabitats (Hedges et al., 2008). Three ecomorphs have been proposed for Caribbean species of Eleutherodactylus: aquatic or semiaquatic, rock-cave, and bromeliad associations (Hedges, 1989). At least thirteen Cuban endemic species of Eleutherodactylus (subgenus Euhyas: E. blairhedgesi, E. etheridgei, E. guanahacabibes, E. bresslerae, E. greyi, E. klinikowskii, E. pezopetrus, E. michaelschmidi, E. pinarensis, E. thomasi, E. tonyi; subgenus Syrrophus: E. symingtoni and E. zeus) are saxicolous, cavernicolous, or live in association with rocks, caves, or limestone landscapes (Díaz et al., 2007; Henderson and Powell, 2009). Most are known to occur in semidarkness at or near the entrance or in absolute darkness deeper in caves.

Both Cuban endemic species of subgenus Syrrhophus, E. symingtoni and E. zeus, are large, have short vomerine dentigerous processes, and share distinctive canthal tubercles (Schwartz, 1958; Hedges et al., 2008). They have become adapted to life in caves, rock crevices, and other sheltered sites in limestone landscapes associated with forest habitats (Henderson and Powell, 2009). Unlike the first species, Eleutherodactylus (Syrrhophus) zeus can be locally common in the Sierra del Rosario and the Sierra de Los Organos, in the Cordillera de Guaniguanico in Western Cuba. It has crepuscular to nocturnal activity, but active individuals have been sighted inside the caves during the day (Estrada et al., 1986). According to Alonso et al. (2007), adults of both sexes vocalize at night from the ground and rocks inside and outside caves. Males produce at least three different types of calls, including advertisement and distress calls (Díaz and Cádiz, 2008). Until now, the breeding activities, egg deposition sites, clutch size, and parental care were unknown. This contribution is the first account of the reproductive behavior and clutch characteristics in a Cuban giant frog, Eleutherodactylus (Syrrophus) zeus, for which we describe four clutches of eggs, nest sites, and presence of parental care from a karstic locality in western Cuba.

\section{Materials And Methods}

All the surveys were performed during the daytime. The observations were made in two areas inside of the Gran Caverna de Santo Tomás, located in Sierra de Quemados,

\footnotetext{
* Corresponding author: ralonso@fbio.uh.cu; robertoalonsous@yahoo.com

${ }^{1}$ Museo de Historia Natural "Felipe Poey", Facultad de Biología, Universidad de La Habana. Calle 25 \# 455 e/ J e I. Vedado. Plaza de la Revolución. CP10400. La Habana, Cuba.

${ }^{2}$ Museo de Historia Natural "Tranquilino Sandalio de Nodas". Martí 202, esquina Comandante Pinares, Pinar del Río. CP. 20100.

${ }^{3}$ Facultad de Biología Universidad de La Habana. Calle 25 \# 455 e/ J e I. Vedado. Plaza de la Revolución. CP10400. La Habana, Cuba.
} 


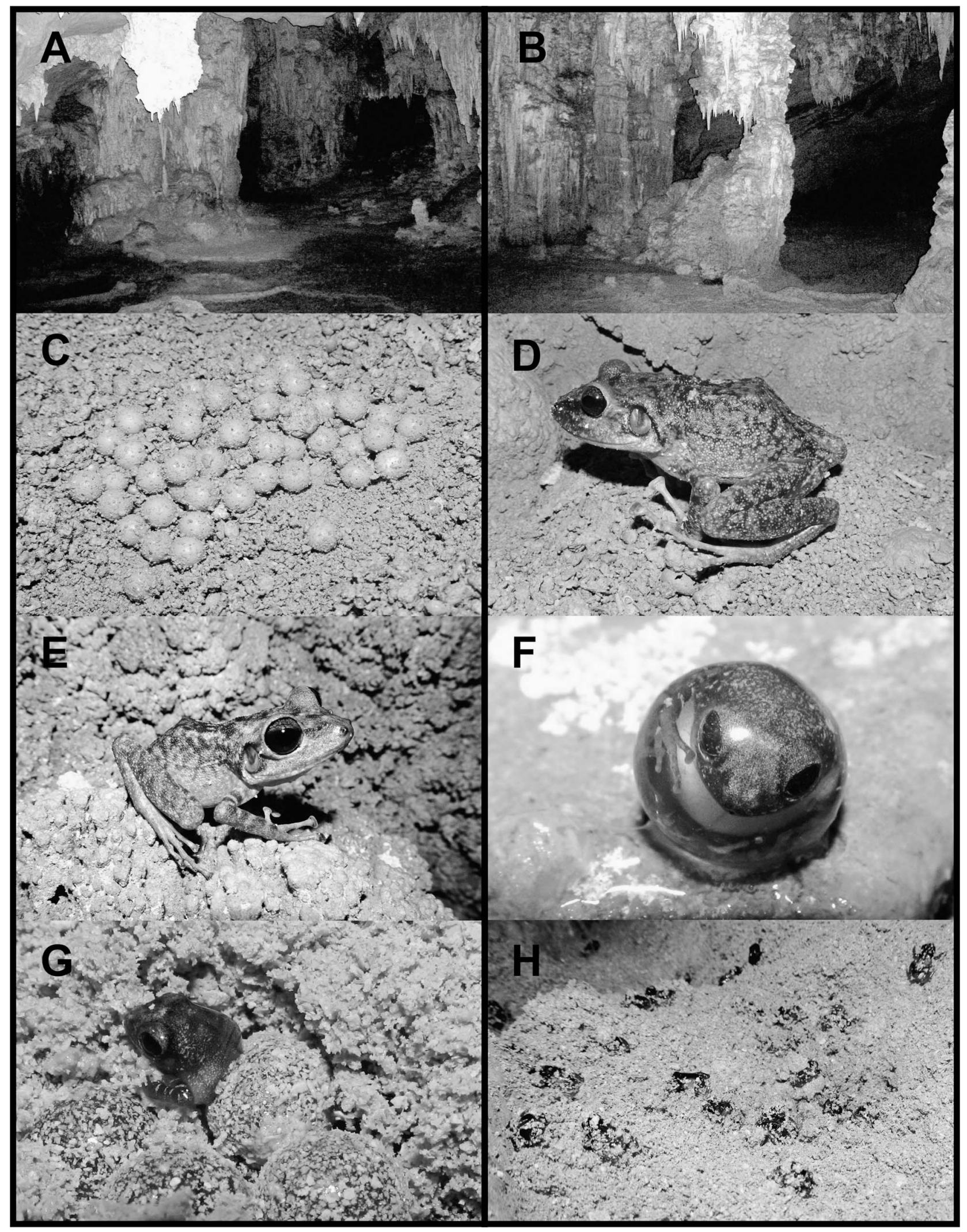

Figure 1. A. Las Perlas area in the Gran Caverna de Santo Tomás, Viñales, Pinar del Río province, Cuba. B. Incognita area, also in the Gran Caverna de Santo Tomás. C. First clutch sighted in Las Perlas, with eggs in three or four developmental stages. D. Eleutherodactylus zeus female attending eggs. E. Eleutherodactylus zeus male near the first clutch. F. Developing 
Viñales municipality, Pinar del Río province, Cuba $\left(83^{\circ} 50^{\prime} 37.024^{\prime \prime} \mathrm{W} ; 22^{\circ} 32^{\prime} 42.863^{\prime \prime} \mathrm{N}\right)$. This is one of the larger cave systems in Cuba, with more than $46 \mathrm{~km}$ of explored galleries. It exhibits a great diversity of secondary karstic formations, some of them uncommon in Cuba (Luis, 2000). Using headlamps we inspected the roofs, walls, and floors in the entrance, semidark, and dark zones.

We measured the air temperature $\left( \pm 0.5^{\circ} \mathrm{C}\right)$ and relative humidity $( \pm 5 \%$ ) using a thermohygrometer (HANNA Instruments). The animals were captured by hand and their snout-vent lengths were measured to the nearest $0.1 \mathrm{~mm}$ using calipers. After this procedure, all were released at the site of collection.

\section{RESUlts}

We found two clutches in different stages of development in the Las Perlas area (Fig. 1A), Gran Caverna de Santo Tomás, Viñales, Pinar del Río, Cuba, at 17:20 on 1 May 2014. The following day at 15:25 we discovered a third nest in the Incógnita area (Fig. 1B), also inside the same system.

The first clutch was in total darkness, 20 to $30 \mathrm{~m}$ from the nearest entrance of the cave, in the soil of a rounded crevice. The clutch of forty-eight white-cream eggs, one measuring $6.5 \mathrm{~mm}$ in diameter, was among granules of secondary karstic formations approximately one millimeter in diameter (Fig. 1C). An undisturbed adult female E. zeus (93.4-mm snout-vent length) was sitting on the nest (Fig. 1D). A male conspecific (67.6-mm SVL; Fig. 1E) was sitting $1 \mathrm{~m}$ away. Air temperature measured near the site of oviposition was $20.8^{\circ} \mathrm{C}$, and the relative humidity $88.3 \%$.

We located the second clutch $5 \mathrm{~m}$ from the first nest, inside a 22-cm deep depression. Unlike the eggs of the first nest, eggs of this nest were covered by very moist soil. The clutch contained fifty-four large eggs, one measuring 9.5 $\mathrm{mm}$ in diameter, with completely pigmented and developed embryos that exhibited considerable mobility (Fig. 1F). Within a few minutes of discovery, fifth-four of the eggs $(98 \%)$ hatched (Fig. 1G), and the froglets, one measuring 11.6-mm SVL, dispersed quickly along the ground to approximately $1 \mathrm{~m}$ from the nest (Fig. $1 \mathrm{H})$.

The next day, we detected a third clutch in a very early stage of development in the Incógnita area in a dark zone approximately $120 \mathrm{~m}$ from the entrance. The nest was located on a mound $5 \mathrm{~cm}$ above the ground. All sixty-four creamy-brown eggs, one measuring $6.3 \mathrm{~mm}$ in diameter, were completely covered with substrate. In order to estimate the clutch size and to measure one of the eggs, we had to temporarily remove an adult individual thought to be a male (67.7-mm SVL) that was positioned along the edge of the nest. Upon release at the site of capture, the frog emitted low, brief, and discontinuous vocalizations. When we inspected the site approximately one hour later, the male was at the same position and location.

In March 2010, one of us (LYG) had found a clutch of similar design and construction as those found in 2014, also deposited on a small mound $10 \mathrm{~cm}$ above the ground in complete darkness in Las Perlas area. The nest, also covered by soil, contained seventy-four yellow-cream spherical eggs in an early developmental stage, adhered together to form a semicircular group. Air temperature measured inside the cave was $20.6^{\circ} \mathrm{C}$ and relative humidity was $97.4 \%$. The closest individual detected was an adult female $E$. zeus $1.1 \mathrm{~m}$ above the nest on the nearest wall.

\section{DisCUSSION}

The intraspecific variation in eggs and clutch size has been studied in several species of anurans. Such variation is evident in comparisons among populations, among individual females in the same populations, and even within clutches of eggs produced by individual females (Wells, 2007). A positive correlation between clutch size and female body size has been reported for some species of Eleutherodactylus (Crump, 1974; Townsend and Stewart, 1994). The clutch-size differences among the four described nests of E. zeus could be a result of the variability in female size; females up to $127.4 \mathrm{~mm}$ in snout-vent length have been measured (García, 2012). However, in our largest clutch of seventy-four eggs we do not discard the possibility of communal nesting. This has been suggested for another Caribbean cave-dwelling frog, E. cooki from Puerto Rico (Rivero, 1978; Joglar et al., 1996; Burrowes, 2000).

Parental attendance of clutches affords a degree of protection from predation, parasitism, desiccation, and fungal attack (Taigen et al., 1984; Townsend et al., 1984; Duellman, 1989). Our contribution is the first report of attendance of eggs by frogs in the subgenus Syrrophus. Published information about two other species, Eleutherodactylus (Syrrophus) marnockii, also considered saxicolous and to some extent cavernicolous in nature, and Eleutherodactylus (Syrrophus) cystignathoides, does not include data about parental care in chirping frogs (Jameson, 1955; Hayes-Odum, 1990).

Parental care in the form of nest attendance has been documented in other Cuban Eleutherodactylus (E. albipes, E. atkinsi, E. dimidiatus, E.guantanamera, E. intermedius, E. leberi, E. tetajulia, and E. varleyi), but none of them is a rock-cave dwelling species. They nest on the ground, in leaf litter, or in elevated sites such as leaf axils of

Eleutherodactylus zeus at stage 14-15. G. Neonate emerging from the egg in Las Perlas area. H. Neonatal Eleutherodactylus zeus after the simultaneous hatching of the same clutch. Photographs by Sergio L. Domínguez and Eduardo López. 
bromeliads and tree holes (Wells, 2007). Rodríguez and Alonso (2009) found a male E. leberi, an endemic Cuban frog of the subgenus Eleutherodactylus, vocalizing near a clutch of twenty-seven eggs in a small cavity in the rocky wall, which was considered evidence of territorial defense of oviposition sites. Our observations raise the possibility of biparental care in Eleutherodactylus (Syrrophus) zeus, in light of the presence of both sexes near nests. Similarly, both male and female parental care was found to occur in E. alticola from Jamaica and E. johnstonei from the Lesser Antilles (Townsend, 1996; Wells, 2007).

Many aspects of the natural history of Eleutherodactylus (Syrrophus) zeus are still unknown. Daily activity, abundance, demography, diet, predators, and particularly their reproductive biology have not been adequately studied (Alonso and Rodríguez, 2003). We do not believe this Cuban rock-cave frog fits well within the classic ecological classification of cavernicoles of Racovitza (1907). Instead, we prefer to classify them as subtroglophiles, in accordance with the terminology suggested by Sket (2008). These are species that inhabit, perpetually or temporarily, a subterranean habitat, but are bound to the surface for some biological functions, such as feeding.

Caves and karst regions are fragile ecosystems that have unique scientific value. These environments provide habitats for secretive and rare endangered species, and they provide opportunities to study complex ecological relationships between cave- and surface-dwelling species. However, human activities are transforming and destroying the cave systems through intentional or accidental damage as a consequence of digging, exploration, and tourist visits and the associated disturbance that inevitably accompanies these activities. Consequently, these practices put at risk the survival and reproduction of of troglophilic and troglobitic faunas. Restricting access and indiscriminate use of karstic resources will enhance the likelihood of conserving poorly studied, at-risk endemic lineages such as Eleutherodactylus (Syrrophus) zeus.

\section{ACKNOWLEDGEMENTS}

We thank Eduardo López, (Director of the National Speleological Training Center, CNEE) and his co-workers at CNNE for their hospitality. We are very grateful to Maikel Lledía for his assistance during the exploration of the Gran Caverna de Santo Tomás. Walter E. Meshaka, Jr., and two anonymous referees provided helpful comments to enhance the quality of this manuscript.

\section{REFERENCES}

Alonso, R., and Rodríguez, A., 2003, Insospechados habitantes de las penumbras, in Rodríguez-Schettino, L., ed., Anfibios y Reptiles de Cuba: Vaasa, Finland, UPC Print, p. 20-29.

Alonso, R., Rodríguez, A., and Márquez, R., 2007, Sound Guide of the Amphibians from Cuba (Audio CD \& booklet): Barcelona, ALOSA sons de la natura.
Burrowes, P.A., 2000, Parental care and sexual selection in the Puerto Rican cave-dwelling frog, Eleutherodactylus cooki: Herpetologica, v. 56, p. 375-386.

Crump, M.L., 1974, Reproductive Strategies in a Tropical Anuran Community: Lawrence, Kansas, Museum of Natural History University of Kansas, Miscellaneous Publication 61, 68 p.

Díaz, L.M., and Cádiz, A., 2008, Guía Taxonómica de los Anfibios de Cuba: Belgium, Abc Taxa, 4, 294 p.

Díaz, L.M., Cádiz, A., and Navarro, N., 2007, A new rock dwelling frog of the genus Eleutherodactylus (Amphibia: Leptodactylidae) from eastern Cuba, with comments on other species with similar habits. Zootaxa, no. 1435 , p. 51-68.

Duellman, W.E., 1989, Alternative life-history styles in anuran amphibians: Evolutionary and ecological implications, in Bruton, M.N., ed., Alternative Life-History Styles of Animals, Dordrecht, Kluwer Academic, Perspectives in Vertebrate Science 6, p. 101-126.

Estrada, A.R., Novo Rodríguez, J., and Moreno, L.V., 1986, Las ranas del grupo symingtoni, género Eleutherodactylus (Anura: Leptodactylidae) de Cuba, Poeyana, no. 329, 14 p.

García, L.Y., 2012, Eleutherodactylus zeus (Cuban Giant Frog). Record size: Herpetological Review, v. 43, p. 631.

Hayes-Odum, L.A., 1990, Observations on reproduction and embryonic development in Syrrhophus cystignathoides campi (Anura: Leptodactylidae): Southwestern Naturalist, v. 35, p. 358-361.

Hedges, S.B., 1989, Evolution and biogeography of West Indian frogs of the genus Eleutherodactylus: Slow-evolving loci and the major groups, in Woods, C.A., ed., Biogeography of the West Indies: Past, Present, and Future, Gainesville, Florida, Sandhill Crane Press, p. 305-369.

Hedges, S.B., Duellman, W.E., and Heinicke, M.P., 2008, New World direct-developing frogs (Anura: Terrarana): Molecular phylogeny, classification, biogeography, and conservation, Zootaxa, v. 1737, $182 \mathrm{p}$.

Henderson, R.W., and Powell, R., 2009, Natural History of West Indian Reptiles and Amphibians: Gainesville, Florida, University Press of Florida, $520 \mathrm{p}$.

Jameson, D.L., 1955, The population dynamics of the cliff frog, Syrrhophus marnocki: American Midland Naturalist, v. 54, p. 342-381.

Joglar, R.L., Burrowes, P.A., and Ríos, N., 1996, Biology of the Puerto Rican cave-dwelling frog, Eleutherodactylus cooki, with some recommendations for its conservation, in Powell, R., and Henderson, R.W., eds., Contributions to West Indian Herpetology: A Tribute to Albert Schwartz, Ithaca, New York, Society for the Study of Amphibians and Reptiles Contributions to Herpetology 12, p. 251-258.

Luis, M.L., 2000, Evaluación para la protección de los mogotes de la Sierra de los Órganos y el Pan de Guajaibón [MS thesis]: Havana, Cuba, Facultad de Geografía, Universidad de La Habana.

Racovitza, E.G., 1907, Essai sur les problèmes biospéologiques: Archives de Zoologie Experimentale et Generale, v. 6, p. 371-488.

Rivero, J.A., 1978, Los Anfibios y Reptiles de Puerto Rico (The Amphibians and Reptiles of Puerto Rico): San Juan, Editorial Universitaria, Universidad de Puerto Rico, 375 p.

Rodríguez, A., and Alonso, R., 2009, Eleutherodactylus leberi. Clutch size and parental care: Herpetological Review, v. 40, no. 2, p. 204.

Schwartz, A., 1958, Another new large Eleutherodactylus (Amphibia: Leptodactylidae) from western Cuba: Proceedings of the Biological Society of Washington, v. 71, p. 37-42.

Sket, B., 2008, Can we agree on an ecological classification of subterranean animals?: Journal of Natural History, v. 42, p. 15491563. doi: 10.1080/00222930801995762.

Taigen, T.L., Pough, F.H., and Stewart, M.M., 1984, Water balance of terrestrial anuran eggs (Eleutherodactylus coqui): Importance of parental care: Ecology, v. 65, p. 248-255. doi: 10.2307/1939477.

Townsend, D.S., 1996, Patterns of parental care in frogs of the genus Eleutherodactylus, in Powell, R., and Henderson, R.W., eds., Contributions to West Indian Herpetology: Ithaca, New York, Society for the Study of Amphibians and Reptiles, p. 229-239.

Townsend, D.S., and Stewart, M.M., 1994, Reproductive ecology of the Puerto Rican frog Eleutherodactylus coqui: Journal of Herpetology, v. 28 , p. $34-40$.

Townsend, D.S., Stewart, M.M., and Pough, F.H., 1984, Male parental care and its adaptive significance in a Neotropical frog: Animal Behavior, v. 32, p. 421-431.

Wells, K.D., 2007, The Ecology and Behavior of Amphibians: Chicago, The University of Chicago Press, 1400 p. 